\title{
MAREK SZYMAJDA
}

BOGUSEAWA IDCZAK

ANITA KURAS

MALGORZATA KORBIN

EDWARD ŻURAWICZ

Instytut Ogrodnictwa

Kierownik Tematu: mgr inż. Marek Szymajda Pracownia Genetyki i Hodowli Roślin Sadowniczych, Instytut Ogrodnictwa, ul. Konstytucji 3 Maja 1/3, 96-100 Skierniewice,

tel. 468345406 , e-mail: marek.szymajda@inhort.pl

Prace zostały wykonane $w$ ramach badan podstawowych na rzecz postępu biologicznego w produkcji roślinnej na podstawie decyzji Ministra Rolnictwa $i$ Rozwoju Wsi nr HOR.hn.802.20.2018, Zadanie 77.

\section{Hybrydyzacja oddalona gatunków Prunus cerasifera (ałycza), Prunus armeniaca (morela), Prunus salicina (śliwa japońska), Prunus domestica (śliwa domowa) w celu zwiększenia bioróżnorodności genetycznej w obrębie rodzaju Prunus}

Distant hybridization of the Prunus cerasifera (myrobalan plum), Prunus armeniaca (apricot), Prunus salicina (Japanese plum), Prunus domestica (European plum) species for extending genetic biodiversity within the genus Prunus

Słowa kluczowe: krzyżowanie międzygatunkowe, mieszańce międzygatunkowe, Prunus, embryo rescue

\section{WSTĘP}

Hybrydyzacja gatunków w obrębie rodzaju Prunus jest dość trudna, a jeśli już zachodzi, to charakteryzuje się niską efektywnością. Celem badań była ocena możliwości zwiększenia bioróżnorodności genetycznej w obrębie rodzaju Prunus poprzez zastosowanie hybrydyzacji oddalonej gatunków Prunus cerasifera, Prunus armeniaca, Prunus salicina, Prunus domestica metodą hodowli klasycznej przy wykorzystaniu techniki embryo-rescue. Przyjęta hipoteza badawcza zakłada, że przy pomocy metod konwencjonalnych (hodowla i technika embryo rescue) możliwy jest transfer genów warunkujących cenne cechy biologiczne między wymienionymi gatunkami i uzyskanie 
nowych nie występujących $\mathrm{w}$ naturze genotypów, posiadających skumulowane cenne cechy, występujące obrębie różnych gatunków z rodzaju Prunus. Zakłada się, że pozwoli to poszerzyć istniejącą bioróżnorodność w obrębie tego rodzaju.

\section{CELE TEMATÓW BADAWCZYCH}

W ramach zadania 77 w roku 2018 realizowano 6 tematów badawczych, których celem było:

- Ocena żywotności pyłku form ojcowskich moreli, śliwy japońskiej i ałyczy, użytych do krzyżowań, oraz jego zdolności do kiełkowania (wytwarzania łagiewki pyłkowej).

- Ocena kompatybilności genetycznej wybranych genotypów moreli, śliwy japońskiej, śliwy domowej i ałyczy, użytych jako formy rodzicielskie w programie krzyżowań.

— Ocena zdolności kiełkowania nasion uzyskanych z programu hybrydyzacji oddalonej lub w wyniku wolnego zapylenia kwiatów różnych genotypów ałyczy, moreli, śliwy japońskiej i śliwy domowej, dla określenia form matecznych wytwarzających nasiona o wysokiej zdolności kiełkowania.

- Optymalizacja warunków dla prawidłowego rozwoju 10 tygodniowych zarodków, uzyskanych w wyniku hybrydyzacji oddalonej w obrębie rodzaju Prunus.

- Opracowanie profili genetycznych dla form rodzicielskich, użytych w zrealizowanym programie krzyżowań oraz zweryfikowanie statusu mieszańca $\mathrm{z}$ planowanego zapylenia dla roślin potomnych uzyskanych w $2017 \mathrm{r}$.

- Ocena wybranych cech biologicznych siewek mieszańcowych uzyskanych w latach 2013-2016 dla wytypowania najbardziej wartościowych pojedynków.

\section{OPIS WYNIKÓW}

W temacie pierwszym barwienie acetoorceiną wykazało, że żywotność pyłku form ojcowskich, wykorzystanych do krzyżowań w 2018 r., wynosi od $36 \%$ do $100 \%$. Żywotność pyłku wyrażona jego zdolnością do kiełkowania na pożywkach była niższa od zaobserwowanej po barwieniu acetoorceiną. Metodę acetoorceinową można więc stosować tylko do badań wstępnych, gdyż może wybarwiać ziarna pyłku nieaktywne fizjologicznie. Niezależnie od zastosowanej pożywki najniższą zdolność kiełkowania miał pyłek śliwy japońskiej (0-3\% kiełkujących ziaren), a najwyższą moreli (30-72\%). Obserwacje wzrostu łagiewek pyłkowych przez tkankę transmisyjną szyjki słupka (in vivo), po zapyleniu wewnątrzgatunkowym (kontrola), wykazały, że dorastają one do poziomu zalążka po upływie 48 godzin od naniesienia pyłku na znamię słupka. Natomiast obserwacje prowadzone dla kombinacji krzyżowań międzygatunkowych wykazały, że łagiewki pyłkowe dorastają do zalążka dopiero po upływie 72 godzin po zapyleniu.

W temacie drugim wykonano 20 kombinacji krzyżowań oddalonych i zapylono 4740 kwiatów. Duża liczba zawiązków mieszańcowych opadła w ciągu kilku tygodni po wykonaniu zapyleń, co prawdopodobnie spowodowane było wystąpieniem postzygotycznych barier krzyżowalności. Ostatecznie uzyskano 642 owoce/zawiązki owoców, co stanowi tylko 13,5\% zapylonych kwiatów. Najlepsze zawiązywanie owoców 
w stosunku do liczby zapylonych kwiatów uzyskano w krzyżowaniach mieszańca (ałycza $\times$ śliwa japońska) $\times$ śliwa japońska $(42,6 \%)$ i śliwa japońska $\times$ ałycza $(23,6 \%)$.

Badania $w$ temacie trzecim prowadzono na 788 nasionach mieszańcowych, uzyskanych z krzyżowania genotypów śliwy japońskiej, moreli i ałyczy, z których 724 $(91,9 \%)$ były to nasiona dobrze wykształcone, czyli żywotne. Pozostałe 64 nasiona $(8,1 \%)$ miały silnie zdeformowane liścienie, a więc były to nasiona nieżywotne. Ocenie zdolności kiełkowania poddano tylko nasiona dobrze wykształcone. Pomimo długotrwałej stratyfikacji i pozbawienia nasion endokarpów nie wszystkie nasiona były zdolne do kiełkowania. Łącznie spośród 788 nasion dobrze wykształconych skiełkowało 686, co stanowi 94,8\%. Najlepiej kiełkowały nasiona form matecznych OSL 58, OSL 65 i 'Najdiena' (100\% skiełkowanych nasion), natomiast nieco słabiej nasiona formy matecznej 'Trumlar' (92,6\% skiełkowanych nasion).

Badania w temacie czwartym prowadzono na 81 zarodkach, uzyskanych z krzyżowania międzygatunkowego śliwy japońskiej, ałyczy i moreli oraz na 180 zarodkach (kontrola) uzyskanych w wyniku zapłodnienia wewnątrzgatunkowego (z wolnego zapylenia). Po 10 tygodniach stratyfikacji pozostało 57 żywotnych zarodków z krzyżowań międzygatunkowych i $145 \mathrm{z}$ wolnego zapylenia. W fitotronie uzyskano odpowiednio 31 i 105 roślin. Z zarodków wyłożonych na pożywki MS (Murashige i Skoog) i WPM (Lloyd i McCown) uzyskano więcej roślin niż z zarodków wyłożonych na C2d (Chee i Pool). Z zarodków śliwy japońskiej D 17-73 oraz 'Czernuszka', uzyskano więcej zregenerowanych roślin niż z zarodków ałyczy 'Amelia'.

W temacie piątym przeprowadzano 1722 reakcje amplifikacji, w których wygenerowano 192 amplikony, w tym 173 polimorficznych o długości od 120 do $520 \mathrm{pz}$. Do opracowania profilu genetycznego klonu nr MMG K4 13 2013 22/1 zastosowano zestaw 20 par oligonukleotydów, w reakcji z którymi uzyskano 44 amplikony o długości od 90 do 300 pz. Status mieszańca z planowanego zapylenia potwierdzono dla 38 z 40 testowanych genotypów.

W temacie szóstym obserwacje prowadzono na 180 siewkach mieszańcowych śliwy japońskiej, ałyczy i moreli, z których zaowocowało 69 genotypów, czyli tylko 38,3\% ocenionej populacji. Duża część ocenionych siewek wykształciła zdeformowane kwiaty, w których znajdowało się od kilku do kilkunastu słupków, przy jednoczesnym braku płatków kwiatowych. Wskazuje to na zaburzenia genetyczne siewek, co zapewne spowodowane jest słabą kompatybilnością genetyczną krzyżowanych form rodzicielskich. Wyróżniającą się populacją były siewki z kombinacji krzyżowania mieszańca śliwy japońskiej i ałyczy 'Najdiena' ze śliwą japońską 'Blue Gigant'. W trzecim roku (drugi rok po posadzeniu w polu) każda $\mathrm{z}$ ocenionych siewek w tej kombinacji zakwitła i zawiązała owoce. Z 14 ocenionych genotypów w tej kombinacji, 7 siewek dobrze owocowało i wytwarzało atrakcyjne owoce. Owoce, wytwarzane przez niektóre z tych siewek, odznaczały się dobrym odchodzeniem miąższu od pestki, co w przypadku owoców śliwy japońskiej jest rzadką cechą. 


\section{WNIOSKI}

1. Okres 72 godzin po zapyleniu jest wystarczający do zapłodnienia komórki jajowej w kombinacjach krzyżowań międzygatunkowych w obrębie rodzaju Prunus.

2. Tradycyjna hybrydyzacja oddalona gatunków morela, śliwa japońska i ałycza jest mało efektywna. Uzyskuje się małą liczbę owoców i nasion mieszańcowych w stosunku do zapylonych kwiatów, ale możliwe jest uzyskanie nasion mieszańcowych krzyżowanych gatunków.

3. Duża część nasion uzyskanych w krzyżowaniach oddalonych śliwa japońska $\times$ morela to nasiona nieprawidłowo wykształcone.

4. Efektywność regeneracji zarodków mieszańcowych śliwa japońska $\times$ morela i ałycza $\times$ morela w warunkach in vitro zależy od genotypu zarodków i rodzaju zastosowanej pożywki.

5. Za pomocą wytypowanego zestawu siedmiu oligonukleotydów możliwe jest potwierdzenie tożsamości mieszańców międzygatunkowych śliwy japońskiej, moreli i ałyczy.

6. Najlepszymi cechami fenotypowymi odznaczają się siewki uzyskane ze skrzyżowania genotypów 'Najdiena' i ‘Blue Gigant' [(śliwa japońska $\times$ ałycza) $\times$ śliwa japońska]. 